\title{
Electron Microscopy Images As An Interactive Tool For Cell Biology Modeling And Education
}

\author{
T.C. Araújo-Jorge, ${ }^{*}$ T.S. Cardona, * C.L.S. Mendes*, A. Henriques-Pons, ${ }^{*}$ L.E. Aguiar,** \\ C.M.L.M. Coutinho, ${ }^{*}$ R. Santa-Rita, ${ }^{*}$ C.N. Spiegel, $* * *$ R.M.S. Meirelles, ${ }^{* * *}$ M.NL. \\ Meirelles, $* * * *$ S.L. de Castro, $*$ and H.S. Barbosa ****
}

*Lab. de Biologia Celular \&***Lab. de Biologia Celular de Microorganismos \& ****Lab. de Ultraestrutura Celular, Dept Ultrastructure and Cell Biology, Institute Oswaldo Cruz-Fiocruz, Av. Brasil 4365, Rio de Janeiro, Manguinhos, RJ 21045-900, Brasil. ** CEFETEQ, Rua Lucio Tavares 1045, Centro, Nilópolis, RJ 26530-060, Brasil

Modern cell biology has many challenges in the context of science data explosion. A major one is to rend popular the basic concepts on living cell structures and functions, introducing people to the scientific method [1]. Many authors have stressed that there is an international ongoing crisis in the undergraduate science education and an urgent need to solve it. They addressed issues regarding what went wrong in the traditional teaching process and what needs to be done in the future, such as stressing "science for all students", providing students a supportive learning environment, and having students undertake inquiry-based learning [2]. The use of research data in classrooms is a trend in many countries [e.g. hittp://Www.loci.wisc.edu/outreach/]. For 15 years we developed and performed interactive activities on cell biology in places where they commonly do never happen, such as public squares and favelas in Rio de Janeiro [3]. Given that interactive activities are among the best tools to face this task, we used optical and electron microscopic images (e.g. Figs. 1,3,5,7) obtained in the course of our current research programs, to develop interactive models for biology education. Giant cell models were built for museums (Fig. 6,8), small 2D or 3D models (Fig.4) and for school activities games were constructed by the students and/or their teachers. The giant models were integrated into a set of activities with microscopes in two science museums in Rio (Espaço Ciência Viva/Space for a Living Science, and Museu da Vida-Fiocruz/Life Museum, Fiocruz). They allowed the visitor to walk in a fantasy stage where he is in part an actor and in part a scientist, faced to the challenge of discovering what are those strange bodies/organelles and what are they made for. The models motivated visitors to participate in other exhibits. Model organisms, such as Elodea leaves, magnetic bacteria, or non-pathogenic protozoa that are used in research lab can also be used in the classrooms to advance our understanding of life. They are less costly and have fewer ethical constraints to be used. Modelling cell components with plastic mass (Fig. 4) using real images instead of schemes is also an important activity, since the students are confronted with all the details and relative size and shapes of the different cell organelles and compartments. Developing games to discover cell aspects and functions just as if you were a scientist searching for data, is another source of much interest among the students. Cell water models of are funny 3-D toys that can be constructed easily allowing different perception of a moving/plastic aspect of the cells [4].

\section{References}

[1] P.M. Bhargava Bioch. Educ. 23 (1995) 120-126.

[2] E. L. Chiappetta. Sc. Teacher Oct (1997) 22-26.

[3] TC Araújo-Jorge et al. IOSTE 9 "Int. Org. Sc.Technol.Educ. 1999 Durban, South Africa.

[4]-This work receives support from Fiocruz/CNPq/Faperj 

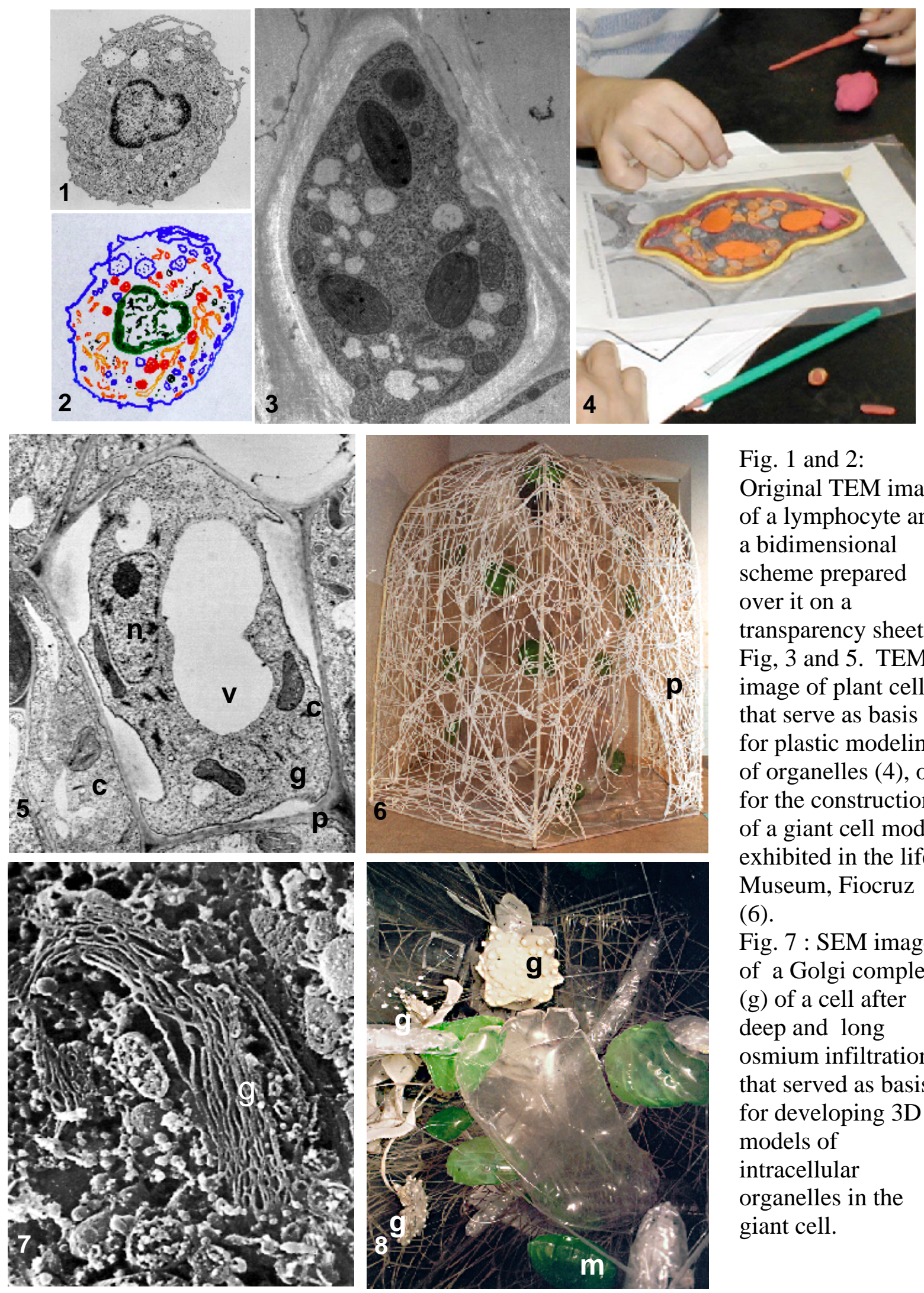

Fig. 1 and 2:

Original TEM image of a lymphocyte and a bidimensional scheme prepared over it on a transparency sheet.. Fig, 3 and 5. TEM image of plant cells that serve as basis for plastic modeling of organelles (4), or for the construction of a giant cell model exhibited in the life Museum, Fiocruz (6).

Fig. 7 : SEM image of a Golgi complex (g) of a cell after deep and long osmium infiltration that served as basis for developing 3D models of intracellular organelles in the giant cell. 